\title{
Beyond kenoticism: Why the suffering God had to become $\operatorname{man}^{1}$
}

\begin{abstract}
From its very beginnings Christianity has believed that the redemption of humanity was dependent upon Incarnation and cross, while simultaneously maintaining the impassibility of the Father. Only in and through the Incarnation could God suffer. In the last century, belief in the impassibility of God has become a minority position; the majority position has become that God is passible. The cross of Christ is then mostly seen as a revelation of that passibility, important but not essential to human salvation. In this paper I argue that belief in God's passibility does not necessitate us to give up the idea that the cross of Christ is constitutive of our salvation. On the contrary, once we have abandoned the limited interpretation of redemption as mere forgiveness and restored the original ideal of redemption as a radical healing of human nature, we can gain some insight why God had to become human to transform human nature from the inside out, as He has done in the Incarnation. Drawing on Aquinas and on C.S. Lewis, I suggest that the idea of good infection and the model of the church as the body of Christ can give us some insight in how the Incarnation and passion of Christ can be effective for all of us.
\end{abstract}

\section{INTRODUCTION}

Cur Deus homo? Why did God have to become a human being? Most traditional answers to this question refer to Jesus' suffering and death, and claim that one way or another God had to become man in order to suffer and die. Thus it is sometimes claimed that in this way Jesus could give satisfaction to God the Father, that in Jesus God took the punishment for our sins upon Himself, or that God by paying a ransom redeemed man from the clutches of the devil (Beilby \& Eddy 2006, Hughes 1949, Mackintosh 1920, Scott 2007). These answers have in common that they make clear why both the Incarnation of the Son of God and His suffering and death were necessary. In the Incarnation and in Jesus' suffering and death God worked the salvation of man. All of the above theories agree on this, that man cannot redeem himself, and that in and through the suffering of the God-man God worked our redemption and our salvation. Thus the Incarnation has a constitutive, salvific function.

The above answers to the question why God became man have in common that they assume that God is by nature impassible (impassibilis), and that only the Incarnation allows God to undergo the suffering that was needed for our redemption. In our time this assumption that God is impassible is no longer widely shared. ${ }^{2}$ Under the influence of a complex of factors the conviction has grown - first and foremost in the British theology (Brierley 2001), and after that in Christian theology in other parts of the world - that God is not impassible, but capable of

1 I would like to thank Gerrit Brand, Brian Leftow and Robin LePoidevin for their helpful comments on earlier versions of this paper.

2 This is not to say that it is entirely without support. Recent studies in support of God's impassibility include Weinandy 2000; Gavrilyuk 2004; Keating \& White (eds.) 2009. 
suffering. If God is capable of suffering, however, then not only the traditional doctrine of the impassibility of God must be abandoned, but the traditional answers to the question why God became man must be revised as well. If God is by nature prone to suffering, then God need not become man in order to be able to suffer and thereby to pay the price for our sins. The question why God became man, is then usually answered as follows. When God forgives our sins, this means that God because of His love for us human beings wants to preserve His relationship with us, and therefore accepts the suffering that we have inflicted on Him by sinning. Who forgives, pays. God's suffering is the price he pays for forgiving and saving us. This has been revealed to us already in the Old Testament (think of Hosea), but only in the suffering and death of Jesus is it revealed to the full extent. The Incarnation reveals us our salvation, and the price God is willing to pay for it. Therefore, we call this the revelatory or illustrative view of the Incarnation: In the incarnate Son, God shows the price that He is willing to pay for our salvation.

Note that on this view Jesus' suffering and death express the price that God pays, but are not that price. This means that on the illustrative view of the Incarnation, both the Incarnation and the suffering and death of Jesus were not necessary for salvation. God has chosen this path as best revealing the price that He pays, but there are obviously other - albeit less perfect revelations of the same price and the redemption gained by it. The Incarnation, suffering and death of Christ thus are no longer essential to Christianity. They are valuable illustrations of something that was already there, not less than that, but not more either. This consequence of the idea that God suffers, is deeply disquieting to many: it seems to reduce the core of Christian faith to an optional extra. It is no longer clear why the Son of Man must suffer. Therefore those who claim that God already prior to and independent of the Incarnation suffers (and therefore is passible) are confronted with the task to show why the Incarnation is still needed. That is what I will try to do in this contribution. By doing so, I follow in the footsteps of Vincent Brümmer, my Ph.D. supervisor, who both first introduced me to the idea that God might be passible and first taught me to think about the question that I will discuss here.

I will proceed as follows. First I will explain how according to traditional, orthodox theology the impassible Son could suffer while remaining impassible. I will then show how the influence of kenotic Christology led to the idea that God incarnate did not remain impassible. Subsequently I will sketch how this kenoticism has radicalized into passibilism, according to which God is passible also apart from the Incarnation. I will not only describe this position but endorse it as well, and finally try to answer why, if God is passible, God should become man.

\section{THE TRADITIONAL VIEW: HOW THE IMPASSIBLE SUFFERED IN JESUS}

In the $21^{\text {st }}$ century, when we talk about the Scandal of the Cross we mean by this that in the Roman empire crucifixion was a deliberately cruel and degrading form of punishment. That the Son of God was killed in this way is experienced as offensive and even scandalous. For the Church Fathers Jesus death on the cross was scandalous in still another way: they were not only shocked by the nature of Jesus' suffering and death, but also by the mere fact of it. In the cultural climate of Hellenism and in the philosophy of the time, feelings and emotions were intrinsically objectionable. ${ }^{3}$ The Greek term for emotion pathos and its Latin equivalent passio are etymologically cognate with "passive". This is no accident: The ancient Greeks thought that emotions - "passions" - are caused by outside forces. Emotions are irrational experiences by which the mind is passively "swayed". People "undergo" emotions, emotions "happen to"

3 See, e.g., Wolterstorff 1988. Wolterstorff shows how Augustine qualifies the view of emotions as intrinsically objectionable in his anthropology, but fails to apply these qualifications in his doctrine of God. 
them, "strike" them, "overwhelm" them. One would be better of without them. This certainly applied to suffering. A-patheia (impassibility) was pursued as an ideal, since it made possible an undisturbed operation of the rational mind. These anthropological views also influenced the doctrine of God. Whatever is disapproved of in human beings, cannot be ascribed to God. Thus the human ideal of apathy also became a characteristic of God (Frohmhofen 1987; Mozely 1926).

On the basis of the unconditionedness (Greek autarkeia, Larin aseitas) of God, the Church fathers came to the same conclusion: God cannot have feelings or emotions. God exists a se -through Godself - that is to say creation is dependent on God both for its beginning and for its continuing existence, and therefore God cannot be dependent upon creation. But if God is independent of the world, God cannot suffer. One always suffers from or under something. Now God is perfect and therefore cannot suffer from some aspect of Godself. If God would suffer, this suffering would have to be caused by some outside force. But that would make God dependent on something apart from God, whereas theology wants to assert that everything that is not God is dependent upon God. Therefore God cannot suffer, nor can God experience any other emotions. This does not imply that the inner life of God does not have a "feeling tone": Christian theology has often described an immutable blissfulness to God (Aquinas: I 26; Randles 1900; Creel 1986:1, 132-139, 144-146, 163-165).

This blissfulness is the point of departure for another argument against divine passibility, in which it is argued that if God is not blissful, human beings cannot reach salvation (Sarot 1992:59-65). Thus, St Augustine argues, fellowship with God is the supreme good. Happiness can be found in this fellowship (Augustine: 4,5,13, and 18; cf. Brümmer 1993:118-126). But what if Godself is not perfectly happy? How can supreme happiness consist in a relationship with someone who suffers from unhappiness? Thus the denial of God's blissfulness also throws doubt upon the possibility that human beings find happiness in fellowship with God.

Summarizing: both their views on the human emotional life and their beliefs about God's unconditionedness and blissfulness provided reasons for early Christians to hold that God must be impassible. The concurrence of these three reasons explains how this belief could become a deep-rooted conviction.

It can easily be understood why the doctrine of divine impassiblity led to tensions in early Christian theology. For if the following three statements are true,

1. God is impassible

2. Jesus is God

3. Jesus has suffered

combined they lead to a fourth statement that - if not contradictory - is highly paradoxical:

4. The impassible suffered.

(2) and (3) find much support in the New Testament. Thus Jesus claims in St John's Gospel that He and the Father are one (10:38) and that who has seen Jesus, has seen the Father (14:9; cf. 1:18). In the same Gospel the crucifixion belongs to the essence of Jesus' mission (12:27; cf. $15: 13)$. It does neither say that the unity of Father and Son is broken at the crucifixion, nor that we cannot see the Father on the cross.

This explains why (4) is not a construction of a theologian in search of a problem, but an adequate rendering of the position of St Cyril of Alexandria $(+444)^{4}$ and of the mainstream of the Christian tradition. How could St Cyril and the theological tradition following him adopt this paradox? How could they claim that in Christ the impassible God suffered without losing His impassibility? Traditionally, theologians answer these questions by referring to the doctrine of

4 It is far from certain that St Cyril literally used this formula. See Weinandy 2000: esp. 202-203. Anselm I 8 also defends the classical position. 
communicatio idiomatum: the perfect interchange of the properties of God and man in Christ. The hypostatic union of the human and the divine nature in the Person of Christ is such that the attributes of both natures can be truly ascribed to this one Person. Thus Christ is omnipotent since omnipotence is an attribute of the divine nature - as well as passible - since passibility is an attribute of the human nature. Since it is the same subject - Christ - Who is God and man, the man in Christ shares the properties of God and vice versa. That is why we can say that St Mary is the "mother of God" (theotokos). If the man Jesus was the son of Mary, the doctrine of communicatio idiomatum allows us to say that the Logos incarnate was the son of Mary, and thus that Mary was the mother of God. But the same person who was born of Mary suffered under Pontius Pilate, was crucified and died. So if we can say that Mary is the mother of God, we can also say that God suffered and died. There is one proviso: the communicatio idiomatum only applies to the conjunction of concrete and concrete, not to the conjunction of abstract and abstract. The divine nature does not share in the attributes of the human nature and vice versa. If God suffered in Christ, this does not mean that the divine nature suffered. It remained impassible. Jesus' divine nature does not share in the attributes of his human nature - and vice versa. It is only by His union with the flesh that the Logos incarnate, though His divine nature remains impassible, can suffer.

The assertion that the impassible Logos, without losing His impassible nature, can suffer by His union with the flesh, is often judged to be incoherent. However, a simple analogy can show that it is not. Of itself an MP3 player is mute (has a mute "nature"), even when its batteries are full et cetera. It can produce electric signals only, and it needs an amplifier with loudspeakers to translate those signals into sounds. In a similar way, if the divine nature is impassible, the incarnate Logos might suffer through the Flesh during the Incarnation, without thereby losing His essential impassibility. Thus there is no contradiction involved in the assertion that the impassible divine Logos became incarnate and suffered.

Before embarking on a discussion of an alternative position, I would like to note that the traditional view of the suffering of Jesus that I have just sketched sits well with the traditional motives for Incarnation as they have been put forward by St Anselm and others.

\section{BRITISH KENOTICISM: HOW THE IMPASSIBLE LOGOS GAVE UP HIS IMPASSIBILITY5}

On the classical interpretation of the Incarnation, Jesus' divine nature remained impassible all through His suffering and death. Nowadays, many are no longer convinced by this position. One of the arguments against it is that it does not do justice to Scripture. A key Bible text in this connection is the Christ hymn of Philippians 2:6-8 (WEB):

6 who, existing in the form of God,

didn't consider it robbery to be equal with God,

7 but emptied himself,

taking the form of a servant,

being made in the likeness of men.

8 And being found in human form,

he humbled himself,

becoming obedient to death,

yes, the death of the cross. ${ }^{6}$

5 On the subject of this section and the next, see Meessen 1989.

6 On the notoriously difficult translation and interpretation of this hymn, see Martin 1967; cf. Marshall 1968. 
On a terminological note, where the English reads "emptied himself", the Greek has heauton ekenoosen. Ekenoosen is etymologically cognate to kenosis; hence the application of kenosis (self-emptying) to Jesus' Incarnation. Hence also the term "kenotic theology" for a theology that claims that the self-emptying of Jesus went so far that in the Incarnation He emptied Himself of His divine attributes. ${ }^{7}$ This implies that the incarnate Logos gave up His impassibility.

St Paul seems to assert that Christ, while aware of the fact that He was by right equal to God, when becoming man gave up His divinity and without reservation took the role of a slave. If one reads the text thus, the crucifixion loses its paradoxical character: the Logos who suffered on the cross had surrendered His impassibility already at the Incarnation. Here, one might say, the crucifixion becomes the ultimate consequence of the Incarnation.

Kenotic theology has ancient roots, that go back at least as far as Luther's theologia crucis (Ngien 1995), which was further developed in the schools of Tübingen and Gießen. A full-blown kenotic theology, however, was developed only under the influence of Hegel in the German theology of the nineteenth century. ${ }^{8}$ German kenoticism also influenced British theology; here, I will concentrate on British kenoticism. ${ }^{9}$ One of the British kenoticists is the undeservedly forgotten theologian Robert Paterson. In his The Philosophy of the Atonement he revisits St Anselm's age-old question: Why did God have to become man? In that connection Paterson says the following:

God ... sacrificed Himself we say, denied Himself, in the person of Jesus Christ. Our Saviour was "God manifest in the flesh"; and it was not the half of Him, so to say, or the one side merely of His complex personality that suffered. I prick my finger. It is not the lower half of me, the material organism, which suffers. I suffer. The mind, the soul, the spirit, the real ego or self suffers. And I could not conceive of our blessed Lord's Divine nature of personality looking calmly on unmoved, untouched by one feeling of grief of sorrow or pang of regret, while the lower and human nature or personality, in indissoluble union of one consciousness, suffered the agony and bloody sweat of Gethsemane and the most terrible distress of the Cross. To me, I say this is wholly unbelievable. ... (I)n a grandly sympathetic manner the Divinity suffered with the humanity. Indeed, even the Father Himself suffered in the suffering of the Son. Of Jehovah the Scripture does not hesitate to say, with reference to Israel, "In all their afflictions He was afflicted". How much more then in the peculiar afflictions of His Beloved? The conclusion is, that the Divine person in closest union, in oneness of consciousness, with the human personality of the suffering Jesus, could not possibly escape all pain and grief and sorrow. ... Well then, God, in assuming human nature, humbled Himself: in and through the assumption of it He suffered with and for man (Paterson 1892:18-20).

This quotation is typical of British kenoticism (Smedes 1953). Contrary to the tradition affirming the impassibility even of the suffering Logos, it is here affirmed that the incarnate Logos at least is not longer impassible. This need not imply a more rigorous denial of God's impassibility, in which the divine nature itself is passible.

Does kenotic theology lead to new answers to the question why God had to become man? One might expect that it does. If God is by nature impassible but empties Himself of this impassibility

7 Less radical forms of kenoticism assert that the incarnate Logos did not give up His divine attributes but only the use of them.

8 The most important names are: Ernst Sartorius (1797-1859), Karl Theodor Albert Liebner (1806-1871), Johann Christian Konrad von Hofmann (1810-1877), Gottfried Thomasius (1802-1875), Franz Hermann Reinhold Frank (1827-1894) en Wolfg. Friedrich Geß (1819-1891). See, e.g., Isaac Dorner 1994:49-81.

9 British kenoticists include Frank Weston (1871-1924), Clarence E. Rolt (1881-1981), William Temple (1881-1944), Charles Gore (1853-1932), Bertrand R. Brasnett (1893-1988), and the group from which Lux Mundi originated. On Rolt, see Brierley 2001: 221-223. 
in the Incarnation, the suffering of the Logos brings a "new experience"10 to God. One might say that by suffering God learns something that He did not know before: How pain feels. ${ }^{11}$ From this, some British theologians have drawn the conclusion that only by the Incarnation has God become omniscient. As David Brown has it:

Some children have the misfortune to be borne without the ability to experience pain and so unless they are educated in time about the consequences of their actions they end up by doing themselves permanent damage, even accidentally killing themselves. However, if they survive to adulthood, then they will have acquired a good knowledge of the consequences of pain, but even so they will remain without any experiential knowledge of what it feels like to be in pain. Similarly it seems to me with God. Of course, without the Incarnation he already had perfect knowledge of the consequences of pain, but only the Incarnation could have brought him knowledge of what it feels like to be one of us (Brown 1989: 55-56).

Here the assumption of passibility becomes an independent motive for Incarnation: to be omniscient, God must become man.

\section{FROM KENOTICISM TO PASSIBILISM: WHY GOD MUST BE PASSIBLE}

The idea that only by the Incarnation God became omniscient has never received much support. Theologians who assume that omniscience and impassibility are incompatible, will generally deny God's impassibility even apart from the Incarnation: The divine nature itself is passible. ${ }^{12}$ This is in fact a radicalization of kenoticism, which is no longer limited to Christology but extended to the doctrine of God: We may speak of a kenosis of God the Father as well. ${ }^{13}$ What are the grounds for this radicalization? A central argument runs as follows: If Jesus merely were God, we might through the doctrine of the communicatio idiomatum reconcile His suffering with the impassibility of God. But Jesus also is the most definitive and most perfect revelation of who God is. "He who has seen me has seen the Father" (John 14:9 WEB: cf. 1:18). If, moreover, the cross is essential to Jesus' mission (as suggested in the Gospel of St John), it is strange to deny that the cross has something to say to us about the Father. This becomes even stranger when one realises that suffering is characteristic not only of the end of Jesus' life, but of the whole of it (Heidelberg Catechism Sunday 15, Answer 37; Karl Barth), and that the gospels therefore are "passion narratives with extended introductions" (Martin Kähler). That precisely the fact that Jesus is taken to be God's ultimate self-revelation leads to the introduction of kenosis into the doctrine of God, can be seen from many texts. I give two examples. The first comes from a book by North-American theologian Douglas John Hall:

If it is really God who is revealed in and through the crucified one, then how can we continue to speak about the divine "impassibility" at all, or at least without subjecting is to

a thorough Christological overhaul! (Hall 1986:215)

That the same conclusion was drawn already at the beginning of the twentieth century can be shown from the following passionate quote from another North-American theologian, Charles Allen Dinsmore:

10 Thus Jürgen Moltmann at a certain stage of his work. For a brief but good description and analysis, see Fiddes 1988:8-9.

11 On the question whether one must have suffered oneself in order to know how pain feels see Sarot 1991a:89-92; Nagasawa 2008.

12 Thus the "Doctrine Commission of the Church of England" 1987, which claims that "Christians, at least in the mainstream traditions, do not say that God as God has to go through suffering in order to learn, develop or mature" (159), while it asserts that "the issue of the suffering of God is confronted, and belief in an impassible God is discarded" (ix).

13 The idea of a kenosis of the Father was already suggested in Fairbairn 1897: 484, 552. 
In Jesus of Nazareth the Eternal Word felt the pangs of the cross. But that three hours' pain was not a spasm ending in unbroken joy. It was symbolical of a perpetual feeling. What Jesus experienced in spiritual revulsion from sin, and his suffering on its behalf, is a revelation of an unchanging consciousness in God. As the flash of the volcano discloses for a few hours the elemental fires at the earth's centre, so the light on Calvary was the bursting forth through historical conditions of the very nature of the Everlasting. There was a cross in the heart of God before there was one planted on the green hill outside of Jerusalem. And now that the cross of wood has been taken down, the one in the heart of God abides, and it will remain so long as there is one sinful soul for whom to suffer (Dinsmore 1906: 232233). ${ }^{14}$

We have seen above that the rejection of divine impassibility in contemporary theology has become so strong, that the Anglican Church distances itself from it in official doctrinal documents. This doctrinal development cannot be explained from Christology only. It is also based on novel exegetical insights into various Old Testament texts ${ }^{15}$ and on the fact that in light of the amount of suffering in the world, a co-suffering God is in the eyes of many more credible than a blissfully impassible God. ${ }^{16}$ A final argument in favour of a suffering God is that in contemporary theology - and in contemporary popular faith - more than in earlier stages of Christian faith and dogma, love has become the defining characteristic of God. And love is not love, it is argued, when it does not at least involve a vulnerability to pain. ${ }^{17}$ Here, I merely sum up these arguments without analyzing them, in order to focus on the question: If God was suffering anyhow, why should he have become man?

In my discussion of these questions I focus on two theologians: Eli Stanley Jones (18841973) en Vincent Brümmer (*1932). Jones was an American Methodist missionary to India who authored 28 books. His is a narrative theology avant la lettre: He articulates valuable theological insights by means of an exposition and analysis of specific examples. In Christ and Human Suffering he tells the following story.

When two young men were guilty of immorality in the Ashram of Mahatma Gandhi it broke his heart. He had preached purity to India, and yet impurity had invaded his own Ashram. Out of sheer sorrow of spirit he began to fast. For six days he fasted. When after this ordeal those boys stood before Gandhi and begged to be forgiven and restored to fellowship, could he do it? Yes, he could offer them forgiveness now, for it would no longer be a cheap forgiveness. It had the stain of the blood of his own suffering upon it (Jones 1933:182). And he concludes from this analogy:

If God offers us forgiveness on the basis of the Divine omnipotence, ... then I am sure that we cannot take it. It lacks moral quality. It is cheap. But if He offers us forgiveness on the basis, not of the Divine omnipotence, but of the Divine self-sacrifice - if He offers it in a nailpierced hand, then our moral sense will let us take it (Jones 1933:183).

The Incarnation and suffering of the Logos remain important for the atonement:

(T)his outward cross that was lifted up in history is a sign of that inward cross that lies upon the heart of God. We who are bound by our senses could not see the inward cross upon God's heart unless and until it was lifted up before our senses. The Italian painter was crudely right, then, when he pictured the nails driven into the hands of Jesus as going through the wood and into the hands of the Father at the back (Jones 1933:168).

14 On contacts between American and British passibilism, see Brierley 2001:229. A British example of the same argument can be found in: Hughes 1924:95, 102.

15 The best study is still Heschel 1962; on the interpretation of key text 1 Samuel 15, see Sarot 2001.

16 On this argument, see Sarot 1991b.

17 On this argument, see Sarot 1992: 80-91. 
Thus the cross reveals the atoning suffering of God, that began already before the Logos became incarnate. Does this not render Incarnation and cross superfluous? For Jones, this is not the case: we could not see the wounded heart of God before it was made visible to us at Golgotha. On this issue, Vincent Brümmer is even more outspoken:

Christ's suffering is not merely the paradigmatic revelation of God's atoning forgiveness. Such a revelation is also a necessary condition for this forgiveness to achieve reconciliation. ... Through $\sin$... we have become estranged from God. ... (T)his estrangement has led to ignorance. Not only do we not know God; we do not even know who God is. For this reason we have lost the ability to seek reconciliation with God. We cannot seek divine forgiveness, for we do not know whether God is longsuffering enough to forgive. In fact, we cannot repent, for we do not know whom we have offended. And since we are unable to repent, God's forgiveness cannot be effective. In the words of John Burnaby, "there can be no effective forgiveness unless the wrong-doer repents of his wrong-doing, knows whom he has offended, and comes back to him with a changed mind ..." (Brümmer 1993:2002; cf Brümmer 2006:413).

In short, forgiveness presupposes repentance. One cannot forgive someone who still approves of his offense(s). Such a person does not even realize that he is in need of forgiveness. In order to become aware of this, a person must know (1) that he has given offense, (2) whom he has offended (3) what the offense consists of. This knowledge human beings no longer have and must be revealed to them. Moreover, Brümmer suggests, human beings will not ask for forgiveness if they do not know that God is prepared to forgive. This willingness to forgive is revealed only at the cross.

At first sight, Brümmer seems to succeed in showing why Incarnation and cross are essential to human salvation, even if God is passible by nature. He shares with the illustrative view of Incarnation and cross the idea that these are revelations of God's purposes; for Brümmer, however, they are not mere revelations but revelations that are necessary for human salvation. ${ }^{18}$ If one compares the history of Christianity with the history of Judaism, however, Brümmer's view loses much of its plausibility. While Christian theologians have almost unanimously asserted the impassibility of God until the nineteenth century, Jewish thinkers have through the ages drawn attention to God's suffering. We have seen above that Biblical scholars nowadays affirm that the dominant image of God in the Hebrew Scriptures is passible. God is depicted as having an anthropomorphous inner life, as loving (Is. 63:9), rejoicing (Zeph. 3:17) repenting (Gen. 6:6), suffering (Is. 63:7, Ex. 3:7-8) and having compassion (Ex. 34:6), but also as being jealous (Ex.20:5), being angry (Hos. 11:9) and hating (Am. 5:21). It is certainly not the case that only in the narrative part of the Hebrew Scriptures feelings and emotions are ascribed to God, so that one might claim that this happens only to embellish the stories, not to make statements about God. On the contrary, emotion terms take pride of place also in more general, confessional statements about God like Ex. 34:6-7 (WEB):

Yahweh! Yahweh, a merciful and gracious God, slow to anger, and abundant in loving kindness and truth, keeping loving kindness for thousands, forgiving iniquity and disobedience and sin; and that will by no means clear the guilty, visiting the iniquity of the fathers on the children, and on the children's children.

This text, which in various forms is repeated time and again in the Hebrew Scriptures, is not presented as conclusion drawn by human beings from the way in which God has acted

18 Still, if one distinguishes with Knitter 2003: 53 between an "ontological fix" in which God does something about what's wrong with the human situation and an "epistemological fix" in which God makes us known what was wrong to begin with, for Brümmer Incarnation and cross figure in the "epistemological fix" only. 
throughout salvation history, but as a direct self-revelation of God. It follows, that the passibility of God belongs to the core of the message of the Hebrew Scriptures (Fretheim 1984:24-29). If, however, God's passibility, God's pity and God's willingness to forgive had been revealed already in the Hebrew Scriptures, the question rises why the Incarnation and suffering of the Logos were still necessary. This question is underscored by the fact that through the centuries, Jews have asserted the suffering of God. In this connection, especially the Rabbinic traditions deserve to be mentioned: They unhesitatingly affirm God's passionate involvement with His chosen people, His suffering, His distress, even His tears (Kuhn 1968 and 1978; Chalier 2003). And if Biblical exegetes nowadays recognize the passionate Nature of YHWH in the Hebrew Scriptures, the first impulse to this insight came from a Jewish thinker, Abraham Joshua Heschel (Heschel 1936 and 1962). On the other hand, Christian theologians unanimously asserted the impassibility of God until the nineteenth century; movements that are now often seen as precursors to contemporary passibilism such as patripassianism, theopaschitism and Luther's theology of the cross, in fact unwaveringly asserted the divine impassibility. ${ }^{19}$ Historical evidence, therefore, speaks against the idea that Incarnation and cross are needed to reveal the price that God is willing to pay for forgiving human beings. This message was received more powerfully in Judaism!

Thus the doubts about the illustrative view of the Incarnation with which I began this paper are reinforced: If Incarnation and cross are revelations of the price the compassionate God is willing to pay for our redemption, and revelations of the inner Trinitarian life of God as it is even apart from the Incarnation, the least we should say is that they are inefficient revelations. Their revelatory function cannot have been their only function. This means that there must have been another reason for the Incarnation and suffering of the Logos. What more can we say about that reason?

\section{WHY THE SUFFERING GOD HAD TO BECOME MAN ${ }^{20}$}

Western theology has often narrowed atonement to forgiveness. Humanity has sinned against God and needs God's forgiveness. Man must confess his guilt, but that does not suffice. Satisfaction must be made (St Anselm), an act of voluntary suffering was needed (St Thomas Aquinas), or someone had to pay the penalty for the sins of human beings in an act of penal substitution (Calvin) - and in this way forgiveness is obtained and atonement achieved either for humanity (St Thomas Aquinas) or for a limited number of elect (Calvin). In either case, atonement involves suffering and God takes this suffering upon Godself - on traditional theology, at the cross, and on the passibilist alternative, already before and apart from the cross. If atonement is limited to forgiveness, a passibilist theology must lead to the conclusion that Incarnation and cross are not constitutive of atonement, but merely reveal it. But is it correct to limit atonement to forgiveness? The English term at-one-ment may be interpreted as pointing in that direction: it is a term we use for repairing broken relationships: after atonement, the two that were separated are one again, and their relationships is restored.

Redemption, however, involves more than the forgiveness of sins and the restoration of a broken relation. Redemption is not merely about the recovery of a relationship, but about the recovery of a man himself, whose very being has been tainted by sin and its consequences.

19 See Sarot 1990 and 1996. Patripassianism (also called modalism) was a Trinitarian heresy: Praxeas and other patripassians insufficiently distinguished between Father and Son while safeguarding the Father's impassibility. Theopaschitism is about the same Theos as that mentioned in Theotokos: God the Son. It was, according to theopaschitism, God the Son who suffered in the flesh. On Luther's theology of the cross see, e.g., McGrath 1985.

20 For this part of my paper I owe inspiration to an unpublished lecture by Kathryn Tanner: Tanner 2003.

This does not mean that I take the position I defend here from Tanner. 
Human will, knowledge and abilities all suffer under the effects of sin; yes, the whole of creation suffers from these. Many of the church fathers argue that it is to recovering true humanity, humanity as it was intended, and not merely to atonement, that the Incarnation and suffering of Jesus are essential. The idea is that, just like sin and imperfection are somehow contagious and have not infected some people only, but all, the sinlessness and perfection of Jesus are contagious as well, and are in principle capable of 'infecting' all humanity. The church fathers have often articulated this idea in a way that is no longer acceptable to contemporary humanity. Thus Gregory of Nyssa (fourth century) personifies death and suggests that at the death of Jesus, death along with the bait of flesh swallowed the hook of His divinity. Thus death was divested of its power, for where life is, death cannot be (Gregory of Nyssa, The Great Catechism 24, p. 494).

However, the same thought can be articulated in different ways as well. Gregory of Nazianzus asserted that in the Incarnation Christ bears "all of me together with everything belonging to it in Himself, so that in Himself He may exhaust the bad, as fire does wax, or as the sun does the mists of earth, and that I may participate in His nature by the blending". ${ }^{21}$ Or, again in the words of Gregory of Nyssa, "Although Christ took our filth upon himself, nevertheless he is not himself defiled by the pollution, but in his own self he cleanses the filth, for it say, the light shone in the darkness, but the darkness did not overpower it". 22 These texts suggest that Jesus, by assuming human nature, cleansed and healed it from the inside.

In my view, these texts help us to understand why the suffering God had to become man. Forgiveness was possible apart from Incarnation and cross. People forgive one another, and God is a forgiving God already in the Hebrew Scriptures. Forgiveness, however, does not suffice to withdraw human beings from the power of sin and evil. That requires a healing that goes through and through and reaches the innermost nature of man. Unlike forgiveness, this healing cannot be effected by a mere external action. It requires a much more intimate entrance of God into human nature than forgiveness, and this is precisely what happened in the Incarnation. Of course, we should not interpret the effects of the Incarnation in terms of instant-efficacy, as if the Incarnation by itself would suffice to cause immediate and complete healing. That would make the cross redundant, and we know that it was not. By going through the various stages of human life from birth to death, Jesus sanctified and healed them. Here also, God's grace works in a historical process: "The Child continued to grow and become strong, increasing in wisdom; and the grace of God was upon Him"(Lk 2:40 NASB). On this interpretation, the redemption of man is no reaction of the Father to the work of the Logos, but the Father brings about our redemption through the Logos. This, then, is a fully constitutive interpretation of Incarnation and cross, and no mere illustrative one.

Of course, this interpretation does not answer all questions. Ultimately, it fails to explain how God redeems human beings from within; it does not offer a step-by-step description of the way in which God brings about our redemption. This is only what could be expected, however, since "God's atoning self-identification with us in our sinful humanity is ultimately beyond human comprehension" (Torrance 1997:163). Though full comprehension is beyond human reach, C.S. Lewis and Thomas Aquinas can help us to take some further steps towards it. Lewis introduced the idea that our redemption can work from within because by becoming Christians we start to share in the life of Christ. We are transformed by "good infection":

Now the whole offer which Christianity makes is this: that we can, if we let God have His way, come to share in the life of Christ. If we do, we shall then be sharing a life which was

21 Gregory of Nazianzus IV 6; my own translation, prepared with reference to the translation by Charles G. Browne and James E. Swallow in The Nicene and Post-Nicene Fathers, 2nd series vol. 7.

22 Gregory of Nyssa, Antirrheticus aduersus Apollinarium 26, quoted by Thomas F. Torrance, The

Trinitarian Faith (Edinburgh 1988), 162. 
begotten, not made, which always existed and always will exist. Christ is the Son of God. If we share in this kind of life we ... shall love the Father as He does and the Holy Ghost will arise in us. He came to this world and became a man in order to spread to other men the kind of life He has - by what I call "good infection" (Lewis 1948: 27-28).

To share in the life of Christ so that He can infect us with the good - how should we picture that to ourselves? Here, I propose, St Paul's idea that the Christian community is the body of Christ, and that Christ is the Head of this body, may be helpful. In 1 Corinthians 12 St Paul both emphasises that all Christians together are Christ's body, and that individual Christians are parts of that body with distinct functions: the community needs all of its members like a body does so. Each member is indispensable, and this especially applies to the weakest members, that should be treated with special honour. At various places, Paul identifies Christ as the Head of this body (Eph. 1:22, 4:15, 5:23, Col. 1:18). As we all know, the functioning of the Head is essential to the body: If anything can infect the body with the good, its Head can. The Body of Christ is crucified (Col. 1: 18-22) and resurrected (1 Cor. 6:14-15) with its Head. Thus, by being members of Christ we can be redeemed. In the words of Thomas Aquinas:

Christ's Passion causes forgiveness of sins by way of redemption. For since He is our head, then, by the Passion which He endured from love and obedience, He delivered us as His members from our sins, as by the price of His Passion: in the same way as if a man by the good industry of his hands were to redeem himself from a sin committed with his feet. For, just as the natural body is one though made up of diverse members, so the whole Church, Christ's mystic body, is reckoned as one person with its head, which is Christ (Aquinas, STh Illa 49,1 c., Dominican tr. 1920).

\section{SUMMARY AND CONCLUSION}

From its very beginnings Christianity has believed that the redemption of humanity was dependent upon Incarnation and cross, while simultaneously maintaining the impassibility of the Father. Only in and through the Incarnation could God suffer. In the last century, belief in the impassibility of God has become a minority position; a majority of Christians believe, and theologians maintain, that God is passible. The cross of Christ is then mostly seen as a revelation of that passibility, important but not essential to human salvation. Being convinced that God is passible, but not being content with a merely illustrative or revelatory function for the cross of Christ, in this paper I argued that belief in God's passibility does not necessitate us to give up the idea that the cross of Christ is constitutive of our salvation. On the contrary, once we have abandoned the limited interpretation of redemption as mere forgiveness and restored the original ideal of redemption as a radical healing of human nature, we can gain some insight why God had to become human to transform human nature from the inside out, as He has done in the Incarnation. Even if God healed human nature from the inside out in Christ, as I have argued, it remains difficult to see in what way this healing extends itself to the whole of humanity. Drawing on C.S. Lewis and Thomas Aquinas, I have suggested that the idea of good infection and the model of the church as the body of Christ can help us to gain at least a burgeoning insight in the ways in which the Incarnation and passion of Christ can be effective for all of us.

\section{BIBLIOGRAPHY}

Aquinas, Thomas. Summa Theologiae.

Anselm of Canterbury. Cur Deus Homo.

Augustine, De moribus ecclesiae catholicae.

Beilby, James K. \& Paul R. Eddy (eds.) 2006. The Nature of the Atonement: Four Views. Downers Grove, IL: InterVarsity Pr. 
Brierley, Michael W. 2001. "Introducing the Early British Passibilists", Journal for the History of Modern Theology 8, 218-233.

Brown, David 1989. "The Problem of Pain", in: Robert Morgan (ed.), The Religion of the Incarnation, Bristol: Bristol Classical Press, 46-59.

Brümmer, Vincent 1993. The Model of Love. Cambridge: CUP.

Brümmer, Vincent 2006. Brümmer on Meaning and the Christian Faith. Aldershot: Ashgate.

Chalier, Catherine 2003. Traité des Larmes: Fragilité de Dieu, Fragilité de l'Âme. Paris: Albin Michel.

Creel, Richard E. 1986. Divine Impassibility: An Essay in Philosophical Theology. Cambridge: CUP.

Dinsmore, Charles Allen 1906. Atonement in Literature and Life. Boston: Houghton Mifflin'Doctrine

Commission of the Church of England' 1987. We Believe in God. London: Church House Pub.

Dorner, Isaac A. 1994. Divine Immutability: A Critical Reconsideration tr. Robert R. Williams \& Claude Welch.

Minneapolis: Fortress Press.

Fairbairn, Andrew M. ${ }^{7} 1897$. The Place of Christ in Modern Theology. London: Charles Scribner's Sons.

Fiddes, Paul S. 1988. The Creative Suffering of God. Oxford: Clarendon.

Fretheim, Terence E. 1984. The Suffering of God: An Old Testament Perspective. Philadelphia: Fortress Press.

Frohnhofen, Herbert 1987. Apatheia tou Theou: Über die Affektlosigkeit Gottes in der griechischen Antike

und bei den griechischsprachigen Kirchenvätern bis zu Gregorios Thaumaturgus. Frankfurt a.M.: P.

Lang.

Gavrilyuk, Paul. The Suffering of the Impassible God: The Dialectics of Patristic Thought. Oxford: OUP, 2004. Gregory of Nazianzus, The Five Theological Orations ed. by Arthur J. Mason (Cambridge: CUP, 1899), IV 6. Gregory of Nyssa, The Great Catechism (Engl. tr. in The Nicene and Post-Nicene Fathers, 2nd series vol. 5). Hall, Douglas John 1986. God and Human Suffering. Minneapolis: Augsburg, 1986.

Heidelberg Catechism, The.

Heschel, Abraham Joshua 1936. Die Prophetie. Krakau: Nakładem Polskiej Akademji Umiejętności.

Heschel, Abraham Joshua 1962. The Prophets. New York: Harper \& Row.

Hughes, Henry Maldwyn 1924. What is the Atonement? London: J. Clarke \& Co.

Hughes, Thomas H. 1949. The Atonement: Modern Theories of the Doctrine. London: Allen \& Unwin.

Jones, Eli Stanley 1933. Christ and Human Suffering. London: Hodder \& Stoughton.

Keating, James F. \& Thomas Joseph White (eds.) 2009. Divine Impassibility and the Mystery of Human

Suffering. Grand Rapids: Eerdmans, 2009.

Knitter, Paul 2003. Introducing Theologies of Religions. Maryknoll, NY: Orbis Books.

Kuhn, Peter 1968. Gottes Selbsterniedrigung in der Theologie der Rabbinen. München: Kösel Verlag.

Kuhn, Peter 1978. Gottes Trauer und Klage in der rabbinischen Überlieferung. Leiden: Brill.

Lewis, C.S. ${ }^{6} 1948$. Beyond Personality: The Christian Idea of God. London: Geoffrey Bles.

Mackintosh, Robert. Historic Theories of Atonement. London: Hodder \& Stoughton, 1920.

Marshall, I. Howard 1968. "The Christ-Hymn in Philippians 2:5-11: A Review Article", Tyndale Bulletin 19, 104-127.

Martin, R.P. 1967. Carmen Christi: Philippians ii. 5-11 in Recent Interpretation and in the Setting of Early Christian Worship. Cambridge: CUP.

McGrath, Alister E. 1985. Luther's Theology of the Cross: Martin Luther's Theological Breakthrough. Oxford: Blackwell.

Meessen, Frank 1989. Unveränderlichkeit und Menschwerdung Gottes. Freiburg i.Br.: Herder.

Mozley, John K. 1926. The Impassibility of God: A Survey of Christian Thought. Cambridge: CUP, 1926.

Nagasawa, Yuyin 2008. God and Phenomenal Consciousness: A Novel Approach to Knowledge Arguments.

Cambridge: CUP.

Ngien, Dennis 1995. The Suffering of God according to Martin Luther's "Theologia Crucis". New York: Peter Lang.

Paterson, Robert 1892. The Philosophy of the Atonement. Glasgow: David Bryce.

Randles, Marshall 1900. The Blessed God: Impassibility. London: C.H. Kelly.

Sarot, Marcel 1990. "Patripassianism, Theopaschitism and the Suffering of God", Religious Studies 26, 36375.

Sarot, Marcel 1991a. "Omniscience and Experience", International Journal for Philosophy of Religion 30, 89-102.

Sarot, Marcel 1991b. "Auschwitz, Morality and the Suffering of God", Modern Theology 7, 135-152. 
Sarot, Marcel 1992. God, Passibility and Corporeality. Kampen: Kok Pharos.

Sarot, Marcel 1996. "Patripassianism and the Impassibility of God", Svensk Teologisk Kvartalskrift 72, 73-81.

Sarot, Marcel 2001. "Does God Suffer? A Critical Discussion of Thomas G. Weinandy's Does God Suffer?”, Ars Disputandi $1<w w w . A r s$ Disputandi.org $>$.

Scott, Waldron 2007. What about the Cross? Exploring Models of Atonement. New York: iUniverse, 2007. Smedes, Lewis B. 1953. The Incarnation: Trends in Modern Anglican Thought. Kampen: Kok.

Tanner, Kathryn 2003. "The Cross and Sacrifice", paper given at the conference of the Society for the Study of Theology on "Theologies of the Cross" in Newcastle, April 2003.

Torrance, Thomas F. ${ }^{2}$ 1997. The Trinitarian Faith: The Evangelical Theology of the Ancient Catholic Church. Edinburgh: T\&T Clark.

Weinandy, Thomas G. 2000. Does God Suffer? Edinburgh: T\&T Clark.

Wolterstorff, Nicholas 1988. "Suffering Love", in: Thomas V. Morris (ed.), Philosophy and the Christian Faith. Notre Dame, Ind.: Univ. of Notre Dame Press, 196-237.

\section{KEY WORDS}

Impassibility

Incarnation

cross of Christ

atonement

kenoticsim

\section{TREFWOORDE}

onlijdelijkheid

inkarnasie

kruis van Christus

versoening

kenotisisme

Marcel Sarot

Professor of Fundamental Theology

Tilburg School of Catholic Theology | Tilburg University | P.O. Box 80.101 | 3508 TC Utrecht

M.Sarot@uvt.nl | tel. +31 134663839 